\title{
Soft Skill Guru dalam Mata Pelajaran Seni Budaya di SMP Garuda Manado
}

\author{
${ }^{1}$ Fernita Hontong, ${ }^{2}$ Deflita Rusly Norsly Lumi, ${ }^{3}$ Meyltsan Herbert Maragani \\ ${ }^{1}$ Mahasiswa Program Studi Pendidikan Musik Gereja IAKN Manado, ${ }^{2}$ Dosen Program Studi \\ Pendidikan Agama Kristen IAKN Manado, ${ }^{3}$ Dosen Program Studi Pendidikan Musik Gereja \\ IAKN Manado \\ 17fernita17hontong@gmail.com, ${ }^{2}$ deflita.stakn@gmail.com, ${ }^{3}$ ilzanmaragani@iakn-manado.ac.id
}

\begin{abstract}
Abstrak
Penelitian ini mengkaji tentang Soft Skill guru mata pelajaran Seni Budaya yang dilakukan di SMP Garuda Manado. Tujuan dari penelitian ini adalah untuk mengetahui Soft Skill yang dimiliki oleh guru dalam mengajar mata pelajaran seni budaya di SMP Garuda Manado, serta mengetahui pembelajaran Seni Budaya dari guru yang memiliki Soft skill di SMP Garuda Manado. Metode yang digunakan dalam penelitian ini adalah metode Kualitatif dengan pendekatan deskriptif. Teknik pengumpulan data menggunakan observasi, wawancara dan studi dokumen. Hasil penelitian menunjukan yang menjadi aspek-aspek dalam Soft Skill adalah kemampuan komunikasi, berorganisasi, kepemimpinan, logika, efort skill, kerjasama, dan keterampilan etika. Berdasarkan hasil penelitian maka dapat dikemukakan bahwa Soft Skill harus dimiliki oleh seorang guru, karena dengan memiliki Soft Skill dapat tercapai suatu pencapaian yang saling menguntungkan terhadap guru dan siswa.
\end{abstract}

Kata Kunci: Soft Skill, Guru Seni Budaya

\begin{abstract}
This study examines the Soft Skills of the teachers in the Cultural Arts subject at SMP Garuda Manado. The purpose of this study was to determine the soft skills possessed by teachers in teaching arts and culture subjects at Garuda Manado Junior High School, as well as to find out about learning and cultural arts from teachers who have soft skills at SMP Garuda Manado. The method used in this research is a qualitative method with a descriptive approach. Data collection techniques using observation, interviews and document study. The results showed that the aspects of Soft Skills were communication skills, organization, leadership, logic, efort skills, cooperation, and ethical skills. Based on the results of the research, it can be argued that the Soft Skill must be owned by a teacher, because by having Soft Skills, an achievement that is mutually beneficial for teachers and students can be achieved.
\end{abstract}

Keywords: Soft Skill, Cultural Arts Teacher 


\section{Pendahuluan}

Kemampuan dasar yang ada dalam diri seseorang dan keterampilan personal yaitu keterampilan khusus yang bersifat non-teknis, tidak berwujud, dan kepribadian yang menentukan kekuatan seseorang sebagai pendidik, pemimpin, dan mediator konflik, perlu ditumbuhkan, agar dapat memotivasi diri dan orang lain, bertanggung jawab, membangun relasi, berkomunikasi, beradaptasi dengan lingkungan, berkreasi, berinovasi dan berwirausaha, memimpin, membangun kerja sama, dalam hal ini dimaksudkan dengan Soft Skills. Soft Skills sangat berpengaruh terhadap dunia pendidikan apalagi kepada tenaga pendidik (guru).

Soft Skill merupakan kepribadian, sosial, dan komunikasi dalam manajemen perilaku diri seseorang. Soft Skill juga mempunyai beberapa cakupan yaitu kesadaran diri dalam berpikir kritis, pemecahan masalah, mengambil resiko serta memanajemen waktu dalam pengendalian diri integritas, rasa percaya diri, empati, berinisiatif, dan bersikap, layak dipercaya, sifat berhati-hati, serta kemampuan dalam menyesuaikan diri dalam keadaan apapun.

Mata pelajaran Seni Budaya, dan Keterampilan merupakan salah satu mata pelajaran yang menuntut keterampilan seorang guru dalam mengorganisasi materi pembelajaran dan memberikan demonstrasi lagu dan permainan alat musik. Hal ini mengindikasikan bahwa mata pelajaran pendidikan seni dipelajari melalui teori dan praktik.

Pada dasarnya, proses pembelajaran memiliki beberapa komponen yaitu: Peserta didik, guru (sebagai pendidik), tujuan pembelajaran, isi pembelajaran, media dan evaluasi. Proses pembelajaran tidak akan berjalan dengan baik jika dari salah satu komponen tersebut ditinggalkan. Dari komponen itu maka yang sangat berperan dalam proses pembelajaran adalah Guru, sebab guru sebagai narasumber, mediator, instruktur dalam suatu proses belajar mengajar.

Berdasarkan pengamatan yang dilakukan bahwa proses pembelajaran Seni Budaya Keterampilan (SBK) di SMP Garuda Manado pada umumnya belum dapat dilaksanakan sesuai dengan tuntutan kurikulum. Hal ini dikarenakan di SMP Garuda Manado, guru yang mengajar seni budaya merupakan guru yang bukan berlatar belakang seni, melainkan guru bahasa Inggris. Hal ini terjadi karena adanya kekurangan guru yang berlatar belakang pendidikan seni, serta adanya kebijakan untuk mencukupi jam pelajaran seorang guru di sekolah tersebut, maka pimpinan mengambil keputusan untuk menugaskan guru bahasa Inggris menjadi guru pengampuh 
mata pelajaran seni budaya. Faktanya, guru tersebut tidak memiliki soft skill dalam mengajar seni budaya. Misalnya, dalam proses belajar mengajar materi tentang seni tari, guru tersebut menugaskan keponakannya untuk mengajar seni tari tersebut. Begitu pula dengan materi seni musik, guru tersebut memberikan materi cara bermain gitar sementara dirinya tidak bisa memainkan gitar. Oleh karena itu, guru menugaskan kepada peserta didik untuk mengakses youtube melihat tutorial cara belajar gitar.

Tidak adanya guru yang berlatar belakang pendidikan Seni Budaya menyebabkan adanya penempatan guru SBK yang tidak sesuai dengan kompetensi sebagai layaknya guru SBK yang ideal. Hal ini menunjukkan bahwa selain kompetensi guru yang sesuai dengan bidangnya, ternyata ada hal yang tidak kalah penting yang harus dimiliki oleh seorang guru yaitu Soft Skill. Dengan Soft Skill yang dimiliki oleh seorang guru, maka akan membantu guru dalam melakukan tugasnya sebagai pengajar dan menanamkan nilai-nilai etika serta keterampilan kepada siswa serta meningkatkan kualitas metode pembelajaran guru. Berdasarkan fakta dan fenomena di atas maka menarik untuk diteliti tentang Soft Skill Guru Dalam Mata Pelajaran Seni Budaya di SMP Garuda Manado.

Guna membingkai penelitian ini, pembahasan dalam penelitian ini akan diuraikan dengan berpijak pada beberapa konsep, antara lain konsep soft skill yang dikemukakan oleh Kaipa, $P$ \& Millus, $T$ Soft Skill merupakan jenis keterampilan yang lebih banyak terkait dengan sensitivitas perasaan seseorang terhadap lingkungan di sekitarnya. Karena itu dampak yang diakibatkan lebih abstrak namun tetap bisa dirasakan seperti perilaku sopan terhadap lingkungan baru, disiplin diri, keteguhan hati, kemampuan untuk dapat bekerjasama dengan baik secara tim, membantu orang lain, dan sebagainya yang kemudian akan digunakan sebagai indikator terhadap variabel Soft Skill dalam penelitian ini. ${ }^{1}$ kemudian peneliti juga menggunakan konsep

Soft Skill dapat digolongkan ke dalam tiga aspek Pertama, kecakapan mengenal diri (self-awareness) yang biasa disebut kemampuan personal (personal skill). Kecakapan ini meliputi:

1. Penghayatan diri sebagai mahluk Tuhan Yang Maha Esa, anggota masyarakat dan warga negara;

2. Menyadari dan mensyukuri kelebihan dan kekurangan yang dimiliki. sekaligus menjadikannya sebagai modal dalam meningkatkan dirinya

\footnotetext{
${ }^{1}$ Kaipa $P$ \& Milus T. Soft Skills are Smart Skills. Diunduh dari http://www.kaipagroup.com, 2005
} 
sebagai individu yang bermanfaat bagi sendiri dan lingkungannya.

Kedua, kecakapan berpikir rasional (thinking skill). Kecakapan ini meliputi: (1) kecakapan menggali dan menemukan informasi (information searching); (2) kecakapan mengolah informasi dan mengambil keputusan (information processing and decision making skills); dan (3) kecakapan memecahkan masalah secara kreatif (creative problem solving skills).

Ketiga, kecakapan sosial (social skill). Kecakapan ini meliputi: kecakapan komunikasi dengan empati (communication skills); (2) kecakapan bekerjasama. $^{2}$ Dengan demikian, soft skill dapat di artikan sebagai kemampuan seseorang untuk mengelolah sikap, kepribadian, atau kebiasaan dalam menyampaikan materi.

\section{Metode Penelitian}

Pada penelitian ini, metode yang digunakan adalah metode kualitatif dengan pendekatan deskriptif. Penelitian kualitatif ialah prosedur penelitian yang menghasilkan data deskriptif berupa katakata tertulis atau lisan dari orang-orang

2 Al Abduwani, T. A. The Value And Development Of Soft Skills: The Case Of Oman. International Journal of Information Technology and Business Management, 2012, h. 87- 88 . dan perilaku yang dapat diamati. ${ }^{3}$ Lokasi penelitian di SMP Garuda Manado, yang dilaksanakan mulai tahap pra observasi pada bulan Oktober 2019 kemudian dilanjutkan pada bulan Juni 2020. Pengumpulan data dilakukan dengan observasi, wawancara dan studi dokumen. Dalam hal ini peneliti melakukan penelitian dengan menggunakan alat-alat bantu dalam mengumpulkan data seperti kamera, alat tulis menulis, dan catatan lapangan, yang digunakan untuk mencatat hal-hal penting yang sedang diamati dan didapati selama melakukan penelitian. Teknik analisis data dimulai sejak pengumpulan data, reduksi data, penyajian hingga tahap verifikasi data

\section{Hasil dan Pembahasan}

Kompetensi Soft Skill Guru Mata Pelajaran Seni Budaya di SMP Garuda Manado

Latar belakang pendidikan seorang guru menentukan kompetensi terkait tugas dan tanggung jawabnya sebagai seorang guru mata pelajaran tertentu. Tidak sesuainya latar belakang pendidikan seorang guru akan menyebabkan kerja keras guru dalam menyesuaikan tugas dan tanggung jawabnya. Di SMP Garuda Manado ternyata guru pengampu mata pelajaran Seni Budaya dan Keterampilan (SBK)

\footnotetext{
${ }^{3}$ Sumanto, Metodologi Penelitian Sosial Dan Pendidikan, (Yogyakarta: Andi, 1990), h. 5.
} 
bukanlah guru yang berlatar belakang pendidikan seni atau sejenisnya, namun mereka berlatar belakang pendidikan yang berbeda, yaitu Bahasa Inggris.

Namun demikian guru mampu menjalankan tugasnya dengan baik meskipun seringkali menemui hambatanhambatan terkait dengan keterampilan guru. Oleh karena guru memiliki keterbatasan keterampilan maka setidaknya guru mencari solusi dengan cara menambah keterampilan musik melalui private dan kursus mandiri, terutama pemahaman musiknya. Soft Skill guru Seni Budaya dan Keterampilan sangat membantu dalam meningkatkan kualitas pembelajaran selama ini, karena selain aspek pengetahuan yang dimiliki seorang guru aspek keterampilan juga harus dikuasai oleh seorang guru. Aspek Pengetahuan guru berkaitan dengan bidang kognitif. Guru mengetahui teknikteknik mengidentifikasi kebutuhan siswa dan menentukan strategi pembelajaran yang tepat sesuai dengan kebutuhan siswa. Adapun strategi-strategi yang dilakukan oleh guru Seni Budaya dan Keterampilan di SMP Garuda adalah cara menyampaikan materi Seni Budaya khususnya pada materi Seni Musik. Guru mengajak siswa untuk memahami teoriteori musik dengan menggunakan peragaan-peragaan serta memberikan contoh-contoh yang mudah dipahami oleh siswa. Guru juga memiliki strategi pembagian waktu mengajar yang menarik dan tidak membosankan, misalnya ketika suasana sudah mulai monoton guru mengajak siswa menyanyikan beberapa melodi atau memberikan sebuah permainan yang singkat guna mencairkan suasana kembali.

Adapun Aspek Keterampilan yang dimiliki guru berkaitan dengan kemampuan guru dalam menggunakan media dan sumber pembelajaran serta kemampuan membnuat evaluasi pembelajaran dengan baik. Misalnya guru menggunakan media elektronik pendukung dalam menyampaikan materi tentang teori musik. Guru menggunakan alat musik Keyboard untuk membantu siswa memahami tangga nada, selain itu guru menggunakan proyektor untuk menampilkan slide presentasi guru dalam bentuk video dan gambar untuk membantu menjelaskan materi musik yang sedang dibahas. Guru juga memberikan contoh serta mengajak siswa untuk terlibat langsung dalam praktik materi musik, misalnya guru menjelaskan tentang materi Vokal, bagaimana cara bernyanyi yang baik dan teknik pernafasan yang baik. Selain slide yang menunjukkan gambar atau video tentang teknik pernafasan, guru juga langsung memberi contoh kepada siswa bagaimana cara pernafasan yang baik dalam vokal/bernyanyi. Dalam hal ini guru paling tidak memiliki kemampuan dalam mengoperasikan alat musik keyboard dan mengoperasikan komputer serta 
proyektor dengan baik, karena pada masa-masa sekarang ini keterampilan seperti itu sangat dibutuhkan dalam rangka meningkatkan metode pembelajaran yang baik.

\section{Pembelajaran Seni Budaya di SMP Garuda Manado}

Berdasarkan wawancara yang dilakukan kepada Kepala Sekolah, guru Seni Budaya dan Ketrampilan (SBK), dan seorang siswa diperoleh keterangan bahwa menurut mereka proses pembelajaran mata pelajaran Seni Budaya dan Keterampilan masih kurang optimal. Dari sisi penilaian kepala sekolah beranggapan bahwa oleh karena kurangnya Sumber Daya Manusia yang dimiliki oleh SMP Garuda Manado maka dari pohak Kepala Sekolah sempat kesulitan dalam memilih guru yang tepat, namun akhirnya Kepala Sekolah menemukan seorang guru yang dianggap mampu untuk mengampu Mata Pelajaran Seni Budaya dan Keterampilan. Menurut penilaian Kepala Sekolah bahwa guru tersebut selain memiliki kemampuan mengajar yang baik (walaupun latar belakang pendidikan dari Bahasa Inggris) namun ia memiliki pemahaman musik dan notasi musik. Walaupun demikian masih saja ada beberap hal yang masih kurang optimal karena keterbatasan pemahaman, misalnya pemahaman notasi musik yang minim, teknik bernyanyi yang masih di bawah standar dan cara menghimpun siswa yang masih terkadang kurang adanya ketegasan.

Kegiatan belajar di kelas sangat ditentukan oleh guru. Guru hendaknya dapat memilih dan menggunakan metode pembelajaran yang sesuai dengan materi dan bisa menciptakan kondisi kelas yang efektif, karena metode pembelajaran yang menyenangkan memungkinkan siswa untuk aktif dalam pembelajaran.

Menurut Kaipa, P \& Millus T, Soft Skill merupakan jenis keterampilan yang lebih banyak terkait dengan sensitivitas perasaan seseorang terhadap lingkungan sekitarnya. Karena itu, dampak yang diakibatkan lebih abstrak namun tetap bisa dirasakan seperti perilaku sopan terhadap lingkungan baru, disiplin diri, keteguhan hati, kemampuan untuk dapat bekerjasama dengan baik secara tim, membantu orang lain.

Berdasarkan data hasil penelitian yang dilakukan oleh peneliti, peneliti menemukan bahwa dalam penerapan pembelajaran seni budaya, guru mengajar hanya berdasarkan pengetahuannya yang seadanya, pembelajaran secara otodidak dan hanya memberikan tugas tanpa menjelaskan apa isi dari tugas tersebut, sehingga siswa tidak merasa puas karena tidak mengerti dan memahami apa yang diberikan oleh guru.

Pembelajaran Soft Skill sangatlah penting untuk diberikan kepada siswa sebagai bekal mereka terjun ke dunia kerja dan industri, khususnya bagi sekolah 
yang mencetak lulusannya siap dipakai di dunia kerja karena tuntutan dunia kerja lebih menekankan pada kemampuan Soft skill. Menurut Ilah Sailah, pengembangan dan penerapan soft skill hanya efektif jika dilakukan dengan cara penularan. Cara penularan tersebut antara lain:

\section{a) Role Model}

b) Message of the week

c) Hidden Curriculum

Sedangkan menurut Elfindri Dkk, Strategi penerapan soft skill selain diintegrasikan ke dalam proses pembelajaran, dapat juga diterapkan melalui kegiatan ekstrakurikuler. Dari strategi pembelajaran tersebut, dapat disimpulkan bahwa strategi pembelajaran yang dianggap efektif dalam memberikan kemampuan Soft Skill selain dengan pembelajaran langsung, siswa dapat terjun langsung, dan menghadapi situasi, strategi lainnya yang dianggap efektif tentu saja adalah contoh atau model. Dalam hal ini, yang menjadi model adalah guru yang memiliki kemampuan soft skill yang baik.

Dari penjelasan di atas maka dapat dikemukakan bahwa seorang guru harus memiliki Sotk Skill untuk membantu meningkatkan proses pembelajarannya. Latar belakang pendidikan mungkin suatu hal yang mempengaruhi seorang guru dalam mengajar, namun hal itu bukanlah sesuatu yang mutlak, karena Soft Skill seorang guru akan muncul ketika diperhadapkan dengan tantangan- tantagan seperti pada SMP Garuda Manado. Seorang guru yang memiliki latar belakang pendidikan yang bukan kompetensinya tidak menjamin juga bahwa guru itu tidak mampu untuk mengampu Mata Pelajaran. Kemamouan Soft Skill yang dimiliki oleh seorang guru yang akan memampukan guru dalam menjalankan tugasnya sebagai pengajar.

\section{Kesimpulan}

Berdasarkan dari hasil penelitian yang telah dilakukan oleh peneliti di SMP Garuda Manado, maka dapat disimpulkan Soft Skill guru Seni Budaya dan Keterampilan sangat membantu dalam meningkatkan kualitas pembelajaran seni budaya di SMP Garuda Manado. Sebagaimana dikemukakan sebelumnya bahwa pendidikan seni (musik, tari, dll) dipelajari melalui teori dan praktik sehingga perlu adanya pengembangan kompetensi soft skill bagi guru khususnya guru seni budaya di SMP Garuda Manado.

\section{Kepustakaan}

Abduwani, Al T. A. 2012. The Value And Development Of Soft Skills: The Case Of Oman. International Journal of Information Technology and Business Management

Arikunto Suharsimi. 2006. Prosedur Penelitian Suatu Pendekatan Praktik, Jakarta: Rineka Cipta

Bandi. 2009. Pembelajaran Seni Budaya dan Keterampilan, Jakarta:Direktorat 
Jendral Pendidikan Islam Departemen Agama RI

Dawson Catherine, Metode Penelitian Kualitatif Praktis: Sebuah Panduan. Yogyakarta:

Fuad Noor dan Ahmad Gofur. 2009. Integrated Human Resources

Development Berdasarkan Pendekatan CB-HRM, TB-HRM, CBT, dan CPD, Jakarta : PT Grasindo

Ikhsan Putra, S., dan Pratiwi Aryanti. 2005. Sukses dengan Soft Skills. Bandung: ITB

Janawi. 2012. Kompetensi Guru Citra Guru Profesional Bandung: Alfabeta

Karthi L, \& M Mahalakshmi. 2014. Softskills Through Elt Classrooms. Research Journal of English Language and Literature.

Kaipa P \& T Milus. 2005. Soft Skills are Smart Skills. Diunduh dari http://www.kaipagroup.com.

Maragani, Meyltsan. 2016 "Nilai-Nilai Yang Tertanam Pada Masyarakat Dalam Kegiatan Masamper Di Desa Laonggo." Catharsis 5, no. 1: hl. 4854.

Muqowim, 2012. Pengembangan Soft Skill Guru. Yogyakarta: Pedagogia

Nofrion. 2012. Komunikasi Pendidikan Penerapan Teori dan Konsep Dalam Pembelajaran, KENCANA:

Rawamangun- Jakarta.

Prastiwi W 2011. "Pengembangan Soft Skill, Hard Skill dan Life Skill Peserta Didik Dalam Menghadapi Era Globalisasi.

http://www.infodikdas.com"

Sumanto, 1990. Metodologi Penelitian Sosial Dan Pendidikan, Yogyakarta: Andi. 